\title{
Acidification and recovery at mountain lakes in Central Alps assessed by the MAGIC model
}

\author{
Michela ROGORA \\ CNR Institute of Ecosystem Study, L.go Tonolli 50, 28922 Verbania Pallanza, Italy \\ e-mail: m.rogora@ise.cnr.it
}

\begin{abstract}
The dynamic model MAGIC was calibrated and applied to 84 lakes in Central Alps to predict the response of water chemistry to different scenarios of atmospheric deposition of $S$ and $N$ compounds. Selected lakes were representative of a wide range of chemical characteristics and of sensitivity to acidification. The most sensitive lakes have already shown in the latest years signs of recovery in terms of $\mathrm{pH}$ and $A N C$. The model well captured the main trends in lake chemical data. According to the model forecast, recovery at sensitive lakes will continue in the next decades under the hypothesis of a further decrease of acidic input from the atmosphere. Results clearly demonstrated the benefits of achieving the emission reductions in both $S$ and $N$ compounds agreed under the Gothenburg Protocol. Nevertheless, besides the achieved reduction of $\mathrm{SO}_{4}{ }^{2-}$ deposition from the peak levels of the 80s, also $\mathrm{N}$ deposition should be reduced in the near future to protect alpine lakes from further acidification. The condition of lake catchments with regard to $N$ saturation will probably be the dominant factor driving recovery extent. Beside atmospheric deposition, other factors proved to be important in determining long-term changes in surface water chemistry. Climate warming in particular affects weathering processes in lake catchments and dynamics of the $N$ cycle. Including other factors specific to the alpine area, such as dust deposition and climate change, may improve the fit of experimental data by the model and the reliability of model forecast.
\end{abstract}

Key words: atmospheric deposition, water chemistry, modelling, trend, nitrogen

\section{INTRODUCTION}

The reduction of the atmospheric input of acidity in the last two decades has determined a reversal of the acidification processes in surface waters at most European sites. Mountain lakes in particular have proved to respond quickly to change in atmospheric deposition (Mosello et al. 2002; Skjelkvåle et al. 2003). Nonetheless, concentrations of acidity and strong acid anions in lake water are sometime higher than what could be expected on the basis of the strong decline of acidifying inputs, determining a sort of hysteresis in the chemical reversal of acidification (Kopáček et al. 2002). Several processes account for hysteresis, such as mineralisation and desorption of previously stored sulphate $\left(\mathrm{SO}_{4}{ }^{2-}\right)$ in the soil and release of $\mathrm{SO}_{4}{ }^{2-}$ from the organic sulphur (S) pool (Alewell et al. 2000), and nitrogen (N) saturation of the catchments with consequent nitrate $\left(\mathrm{NO}_{3}{ }^{-}\right)$leaching to surface waters (Aber et al. 1989; Wright et al. 2001). Standing the recent decrease of $\mathrm{SO}_{4}{ }^{2-}$ concentrations in surface waters, $\mathrm{NO}_{3}^{-}$plays now a major role in determining the recovery from acidification. Even remote areas are subject to anthropogenic influence by increased $\mathrm{N}$ deposition. The low $\mathrm{N}$ retention in mountainous catchments is related to their peculiarities, including large precipitation amounts, thin soil and sparse vegetation cover as well as possible phosphorus (P) limitations even of terrestrial biota (Kaste et al. 1997).

Alpine lakes are extremely sensitive to several environmental factors other than atmospheric deposition.
Climate change is probably one of the major driving force for the chemical variability of mountain lakes and it can act as a confounding factors in the interpretation of chemical trends related to change in atmospheric emission and deposition (Wright \& Jenkins 2001). Most of the scenarios provided by the Intergovernmental Panel on Climate Change (IPCC) predict a warmer and drier climate in the next future compared to the present situation (IPCC 2001). Moreover according to most General Circulation Models (GCMs), episodes of drought could be more frequent and more severe than at present (IPCC, 2001). In such conditions, processes like $\mathrm{N}$ mineralisation and $\mathrm{S}$ oxidation could be enhanced, with a release of $\mathrm{SO}_{4}{ }^{2-}$ and $\mathrm{NO}_{3}^{-}$to surface water (Mitchell et al. 1996; Wright 1998). Climate warming even on a short time scale (years to decades) accelerates the recovery through an enhanced release of base cations (BC) by weathering (Sommaruga-Wögrath et al. 1997; Rogora et al. 2003a). A further confounding factor is the episodic deposition of Saharan dust, which neutralizes the acidic input associated with atmospheric deposition (Loÿe-Pilot 1986) and represents an important input of alkalinity and nutrients to alpine lakes (Psenner 1999).

Some of these factors and their role in the recovery process have been discussed in previous studies on alpine lakes located in Central-Western Alps, in Lake Maggiore watershed (Rogora et al. 2001, 2003a; Mosello et al. 2002). This region borders South on the most densely inhabited part of the Po Plain, and it is the area which receives the highest $\mathrm{S}$ and $\mathrm{N}$ loads in Italy 
Tab. 1. Selected characteristics of the lakes used in the MAGIC application $(n=84)$. BS: base saturation; ANC: Acid Neutralising Capacity.

\begin{tabular}{|c|c|c|c|c|c|c|c|c|}
\hline & \multicolumn{5}{|c|}{ Percentiles } & \multirow[b]{2}{*}{ Mean } & \multirow[b]{2}{*}{ St. dev } \\
\hline & & $0 \%$ & $25 \%$ & $50 \%$ & $75 \%$ & $100 \%$ & & \\
\hline Altitude & $\mathrm{m}$ & 1692 & 2032 & 2220 & 2399 & 2817 & 2223 & 238 \\
\hline Rocks & $\%$ & 0.04 & 0.8 & 0.88 & 0.92 & 92 & 9.34 & 25.59 \\
\hline Lake area & ha & 0.1 & 0.6 & 1.3 & 4.1 & 25.2 & 2.9 & 3.9 \\
\hline Catchment area & ha & 1.1 & 20.9 & 54.8 & 91.4 & 782.8 & 76 & 93.9 \\
\hline Soil BS & $\%$ & 6.82 & 7.93 & 8.85 & 11.97 & 43.59 & 11.3 & 6.17 \\
\hline $\mathrm{pH}$ & & 4.64 & 6.21 & 6.84 & 7.38 & 9.14 & 6.78 & 0.84 \\
\hline Conductivity & $\mu \mathrm{S} \mathrm{cm}{ }^{-1} 20^{\circ} \mathrm{C}$ & 5.2 & 10.4 & 14.6 & 23 & 148 & 23.4 & 23.8 \\
\hline $\mathrm{Ca}^{2+}$ & $\mu$ eq $1^{-1}$ & 42 & 65 & 105 & 233 & 1372 & 194 & 224 \\
\hline $\mathrm{Mg}^{2+}$ & $\mu$ eq $1^{-1}$ & 3 & 9 & 16 & 38 & 222 & 31 & 38 \\
\hline $\mathrm{Na}^{+}$ & $\mu$ eq $1^{-1}$ & 2 & 12 & 15 & 20 & 97 & 17 & 14 \\
\hline $\mathrm{K}^{+}$ & $\mu$ eq $1^{-1}$ & 2 & 6 & 9 & 13 & 49 & 11 & 9 \\
\hline ANC & $\mu$ eq $1^{-1}$ & -30 & 18 & 65 & 213 & 1429 & 158 & 244 \\
\hline $\mathrm{SO}_{4}^{2-}$ & $\mu$ eq $1^{-1}$ & 18 & 49 & 62 & 79 & 223 & 69 & 35 \\
\hline $\mathrm{NO}_{3}^{-}$ & $\mu \mathrm{eq} \mathrm{l}^{-1}$ & 0 & 14 & 19 & 25 & 51 & 20 & 10 \\
\hline $\mathrm{Cl}^{-}$ & $\mu$ eq $1^{-1}$ & 1 & 4 & 5 & 7 & 74 & 7 & 8 \\
\hline
\end{tabular}

(Mosello \& Marchetto 1996). Survey programs performed in the middle of the 80 s showed how several high-altitude lakes in this area were threatened by acid deposition. The most acid-sensitive lakes were located in Ossola Valley (Italy) and in Canton Ticino (Switzerland), owing to the presence of low-weathering rocks in their catchments and of the limited buffer capacity of their waters (Mosello et al. 1992; Marchetto et al. 1994, 1995). The Ossola Valley and Canton Ticino together formed one of the 13 Lake Districts included in the EMERGE Programme (European Mountain lake Ecosystems: Regionalisation, diaGnostic \& socio-economic Evaluation; Kernan \& Catalan 2003). In total 30 lakes in this district were sampled in 2000 and 2001, but these lakes represent only a small, although representative, portion of the alpine lake population of the entire area. For most of them, data collected during some sampling campaigns in the 1980s (e.g., Marchetto et al. 1994; Boggero et al. 1993) are still the only measured data available. Basing on these data, here we present a regional application of the dynamic model MAGIC (Model of Acidification as Groundwater in Catchment; Cosby et al. 1985a, b, 2001) to reconstruct the acidification process in a high number of lakes since the middle of the 19th century and to predict their response to future changes in the chemistry of atmospheric deposition.

In common with other European sites, the study area has undergone a strong decrease in $\mathrm{SO}_{4}{ }^{2-}$ deposition in the last two decades, due to the effect of reduced emissions of $\mathrm{S}$ oxides in Italy. On the other hand, nitrogen oxides $\left(\mathrm{NO}_{\mathrm{x}}\right)$ and ammonia $\left(\mathrm{NH}_{3}\right)$ emissions as the atmospheric deposition of $\mathrm{N}$ compounds have not changed significantly (Rogora et al. 2001). As a consequence of the decreasing input of acidity, several lakes in the study area showed signs of recovery from acidification in the last 10 years (Mosello et al. 1999; Rogora et al. 2001, 2003a).

Among the lakes in the study area, Lake Paione Superiore (LPS), has become the flag-ship site in some research projects on mountain lakes, namely AL:PE 1 and
2 (Mosello et al. 1995), MOLAR (Mosello et al. 2002) and EMERGE (Kernan \& Catalan 2003). LPS is also included in the International Co-operative Programme on Assessment and Monitoring of Acidification of Rivers and Lakes (ICP-Waters) established under the Executive Body of the Convention on Long-Range Transboundary Air Pollution (CLRTAP).

The results of the model application to LPS, performed within the RECOVER:2010 project (Predicting recovery in acidified freshwater by the year 2010 and beyond; Ferrier et al. 2001) are also shown. For this lake the availability of time trend of measured data and of detailed information about catchment characteristics allowed a more robust calibration than those obtained for the survey lakes. Two different scenarios were applied to discuss the possible role of $\mathrm{N}$ saturation in the future recovery of this lake.

\section{METHODOLOGY}

\subsection{Study sites}

Eighty-four lakes were successfully calibrated with MAGIC and their main characteristics are shown in table 1. These lakes were selected for the modelling on the basis of available chemical data and of their representativity of the whole lake population in the study area, consisting of about 600 lakes greater than 0.1 ha. Forty-eight of the lakes are located in Italy (Ossola Valley), 36 in Switzerland (Canton Ticino). Studies on the chemistry of atmospheric deposition in this area are performed continuously through collaboration between the CNR Institute of Ecosystem Study and the Department of Cantonal Agency for Water Protection of Canton Ticino, which run the sampling stations in the Italian and Swiss parts of the region, respectively. The study area receives high amount of orographic precipitation, between 1100 and $2700 \mathrm{~mm} \mathrm{y}^{-1}$ (Carollo et al. 1985), carried by air masses mainly coming from the South-East. As a consequence, the deposition of acidity and atmospheric pollutant shows a North-South gradient, 
with southern lakes subject to higher deposition that those in the northern part of the area (Mosello et al. 2001).

Most of the lakes are located above the timber line (>2000 $\mathrm{m}$ a.s.1.), in any case in areas not affected by local disturbances or direct anthropogenic sources of pollutants. Land cover in the lake catchments is restricted to small areas of alpine meadow (Marchetto et al. 1995). In most cases soils are thin and cover a limited part of the catchment area. The study area has a very complex geological pattern with a wide range of different lithologies, though most of the catchments (about $75 \%$ of the total) are characterised by acidic rocks. The most common rocks in the Ossola Valley are ortho- and paragneiss, interrupted by marbles, amphibolites and serpentines. In the northern part of the valley, also carbonatic rocks are present. In the area of Canton Ticino bedrock consists mainly of gneiss and calcareous schists (Mosello et al. 1992; Boggero et al. 1993).

The lakes showed a wide range of chemical characteristics and of sensibility to acidification. $\mathrm{pH}$ values in the period of the survey (1980s) were between 4.6 and 9.0. The Acid Neutralising Capacity (ANC), calculated as the sum of base cations $\left(\mathrm{Ca}^{2+}, \mathrm{Mg}^{2+}, \mathrm{Na}^{+}, \mathrm{K}^{+}\right)$minus the sum of strong acid anions $\left(\mathrm{SO}_{4}{ }^{2-}, \mathrm{NO}_{3}{ }^{-}, \mathrm{Cl}^{-}\right)$varied from -30 up to $1300 \mu \mathrm{eq} \mathrm{I}^{-1}$, with half of the lake with values below $65 \mu \mathrm{eq} \mathrm{l}^{-1}$ (Tab. 1). The ionic concentrations in the lakes were generally low, with calcium dominating among cations. In lakes lying in catchments mainly composed by acidic rocks, sulphate is the major anion, while bicarbonate ion dominates in the other lakes (Marchetto et al. 1994). Carbonate weathering was identified as the main process influencing lake chemistry in the study area, with land cover, lithology, lake and catchment area determining the intensity of the process itself (Boggero et al. 1993).

Lakes Paione Superiore is situated in the Bognanco Valley, a lateral of the Ossola Valley, in Central Alps, at $2269 \mathrm{~m}$ a.s.1., in an area not affected by local disturbances or direct anthropogenic sources of pollutants. The only vegetation in the catchment is alpine meadow, and the geo-lithological composition is mostly made up of clear banded orthogneiss and grey gneiss (Mosello et al. 1999). Soils in the catchment proved to be acidic, with low base saturation and an exchange complex dominated by hydrogen and aluminium ions. These features, together with the low ratio of watershed area to lake surface, made LPS extremely sensitive to acidification processes. Indeed this lake proved to be on the most acid-sensitive sites during the surveys performed in the 1980s. Its alkalinity was close to 0 and $\mathrm{pH}$ ranged between 5.3 and 5.8. The ionic content of lake water is very low (about $150 \mu \mathrm{eq} \mathrm{I}^{-1}$ ) and is mainly composed of sulphate, nitrate and calcium. The lake exhibited a marked increase in $\mathrm{pH}$ and alkalinity values in the period 1984-2002 mainly determined by the decrease of sulphate input from the atmosphere (Rogora et al. 2001; Marchetto et al. 2004, this volume).

\subsection{The MAGIC model}

MAGIC (Model of Acidification of Groundwater In Catchments) is a process-oriented, intermediate-complexity dynamic model for the long term reconstruction and future prediction of soil and surface water acidification at the catchment scale (Cosby et al. 1985a, b). It has been in use for more than 15 years and extensively tested on catchments in North America (Cosby et al. 1986) and Europe (Wright et al. 1994; Jenkins et al. 1997), proving to be a suitable method to assess the surface water response to change in acid deposition. The refinements regarding aluminium solubility and organic acids have resulted in improved performance of the model in simulating soil and surface water chemistry. The refined version of the model used here is referred as MAGIC7. An exhaustive description of the model including the most recent refinements is given in Cosby et al. (2001).

\subsubsection{Input data and calibration}

The atmospheric deposition sampling station of Graniga, in operation since 1994, is located quite close to LPS, about $800 \mathrm{~m}$ lower. Data collected at this station were used as input to MAGIC to describe the chemistry of atmospheric deposition affecting the LPS catchment. For the other lakes, the atmospheric inputs to be used in MAGIC were derived from the deposition maps obtained by interpolating precipitation and concentration data, as described in Rogora et al. (2001). Deposition calculated for present day where then scaled to the survey period (1980s) basing on time trend of atmospheric deposition data available for some sampling stations in the study area (Mosello et al. 2001).

Soil processes in MAGIC are represented through a lumped parameter approach, i.e. the model requires spatially aggregated information at the catchments scale for exchangeable BC fractions, depth, cation exchange capacity and bulk density. To collect these information, soil sampling and analysis were performed in 1998 in LPS catchment, and on nine selected catchments in the summer of 2000 and 2001 (Rogora et al. 2003b). Hence soil parameters to be used in MAGIC were hypothesised for the whole lake set basing on measured data available for a few sites and on information about lithology in the catchments.

The calibration of the model was performed simultaneously for all the lakes, applying an automatic calibration routine to the dataset (Cosby et al. 2001). Ten calibrations were tried for each lake and the average value of each variable calculated from the set of successful calibrations. For LPS, the calibration was performed in a sequential manner: after each historical simulation, the outputs were compared to the measured data, the adjustable parameters modified as necessary to improve the fit, and the simulation re-run. This procedure was repeated until no further improvement in the fit could be achieved. The calibration was performed firstly so as to match the observed data of the target year 
(2000), then to obtain the best possible fit to the whole trend of measured data (1984-2000). This gave more reliable calibration results than those obtained using only a mean target value (Rogora et al. 2003b).

Sulphur dynamics are simulated in MAGIC through parameters regulating the $\mathrm{SO}_{4}{ }^{2-}$ retention capacity of soils: the maximum $\mathrm{SO}_{4}{ }^{2-}$ adsorption capacity, $\mathrm{E}_{\mathrm{mx}}$ (meq $\mathrm{kg}^{-1}$ ), and the $\mathrm{SO}_{4}{ }^{2-}$ adsorption half saturation, $\mathrm{C}_{1 / 2}$ (eq $\mathrm{m}^{-3}$ ) (Cosby et al. 1986). The input/output budget of $\mathrm{SO}_{4}{ }^{2-}$ calculated for LPS is towards steady state (Rogora et al. 2001). This situation is probably common to most of the lake catchments considered here, where soils have a limited $\mathrm{SO}_{4}{ }^{2-}$ retention capacity. Hence $\mathrm{E}_{\mathrm{mx}}$ and $\mathrm{C}_{1 / 2}$ were fixed to $0.1 \mathrm{meq}^{-1}$ and $100 \mathrm{eq} \mathrm{m}^{-3}$, respectively.

The weathering of S-containing minerals is an important source of $\mathrm{SO}_{4}{ }^{2-}$ in some of the lake catchments. Basing on the information on lithology, the contribution from weathering was calibrated at each site and resulted in the range of $20-150 \mathrm{meq} \mathrm{m}^{-2} \mathrm{y}^{-1}$. This contribution, as the weathering of $\mathrm{BC}$, was assumed to be constant in time.

$\mathrm{NO}_{3}{ }^{-}$concentrations in alpine lakes has not changed significantly in the last two decades. This emerged from a comparison of chemical data available for the middle 80s with the results of a survey performed in 2000-01 within the EMERGE project (Rogora et al. 2003a). As a consequence, in the multiple calibration a steady-state condition was assumed with regards to $\mathrm{N}$, and the retention capacity of soils and water was supposed not to change in time.

On the other hand, previous studies have shown how the study area is subject to $\mathrm{N}$ deposition among the highest in Europe (20-25 kg ha-1 $\mathrm{y}^{-1}$ as sum of ammonium and nitrate) and some sites in the bordering lowland area showed significant positive trends of $\mathrm{NO}_{3}$ concentrations in the last two decades, indicating a condition of N saturation (Mosello et al. 2001; Rogora et al. 2001). Even if at present this is not the case for high altitude lakes in the Alps, effects of an approaching condition of $\mathrm{N}$ saturation could become evident in the next years if $\mathrm{N}$ deposition remains at current level. To simulate a condition of incoming $\mathrm{N}$ saturation in the catchment of LPS and to evaluate the lake response to different scenarios of $\mathrm{N}$ deposition, $\mathrm{N}$ dynamics included in MAGIC7 were used. The upper $\left(\mathrm{CN}_{\mathrm{UP}}\right)$ and the lower $\left(\mathrm{CN}_{\mathrm{LO}}\right)$ threshold values of the $\mathrm{C} / \mathrm{N}$ ratio in the soil were calibrated at this site. The percentage of inorganic $\mathrm{N}$ immobilised in the soil varies linearly from $100 \%$ to $0 \%$ as the $\mathrm{C} / \mathrm{N}$ ratio of the organic matter declines from $\mathrm{CN}_{\mathrm{UP}}$ to $\mathrm{CN}_{\mathrm{LO}}$ during the simulation (Cosby et al. 2001).

\subsubsection{Applied scenarios}

MAGIC is calibrated through surface water chemistry data of a specific period. For all the lakes the selected target year was 1985, corresponding to the period of the lake survey. The hindcast period was of 140 years (1845-1985), and the forecast performed for the period 1985-2015. LPS was calibrated assuming 2000 as target year and the forecast period was prolonged to 2050. In the framework of the RECOVER:2010 project, the atmospheric deposition sequences were calculated for each cell of the EMEP grid $(150 \mathrm{~km} \times 150 \mathrm{~km})$ using the RAINS model versions 6.1 and 7.5 (Alcamo et al. 1990; Ferrier et al. 2001). For the most recent period modelled deposition were corrected on the basis of measured data available for some sampling sites in the study area (Mosello et al. 2001). Forecast of deposition values for the next years was also provided by the RAINS model. The applied scenario (CLE or Current Legislation Protocol) takes into account the implementation of the most recent Protocols on emission reduction, including the multi-pollutant, multi-effect Gothenburg Protocol (UN-ECE 1999). According to this scenario, the decrease of $\mathrm{SO}_{4}{ }^{2-}$ in Northern Italy will continue in the next years, though less pronounced than the reduction observed in the last 20 years; $\mathrm{NO}_{3}{ }^{-}$deposition is supposed to decrease by $40 \%$ (compared to $2000 \mathrm{lev}$ els) by 2015 , while no variation is envisaged for ammonium $\left(\mathrm{NH}_{4}^{+}\right)$.

\section{RESULTS AND DISCUSSION}

\subsection{Calibration of the MAGIC model}

A successful calibration was achieved for 84 lakes. The sum of acid anions (SAA) and of base cations (SBC) in the lakes as simulated by the model are compared with measured data in figure 1 . Modelled values fit well with measured data in both cases. Only $\mathrm{pH}$ values, in particular below 6.0, were underestimated by the model compared to the measured data. This variable is sensitive to several environmental factors besides the effects of acidifying compounds. Biogeochemical models such as MAGIC usually predict ANC values better than $\mathrm{pH}$, so that the former variable was used here to describe acidification and recovery at alpine lakes.

Reconstructed trends of the major chemical variables in LPS were in good agreement with the measured data at these sites. As an example, figure 2 compares the hindcast simulation by MAGIC with the trends of measured data in LPS. Both $\mathrm{pH}$ and alkalinity has recovered in this lake at a higher extent than it is simulated by the model. Nevertheless the final set of parameters chosen after repeated simulations shows the best agreement with measured data. As discussed below, recent climate changes proved to affect the chemistry of streams and alpine lakes in the study area, in particular as regards $\mathrm{pH}$ and $\mathrm{BC}$ trends (Rogora et al. 2003a). These effects should be considered when dealing with long-term trends of water chemistry, but at present in dynamic models on acidification like MAGIC they cannot be accounted for.

\subsection{Model application}

\subsubsection{Survey lakes}

The MAGIC model was applied to the whole group of lakes to reconstruct the water chemistry in the pre- 

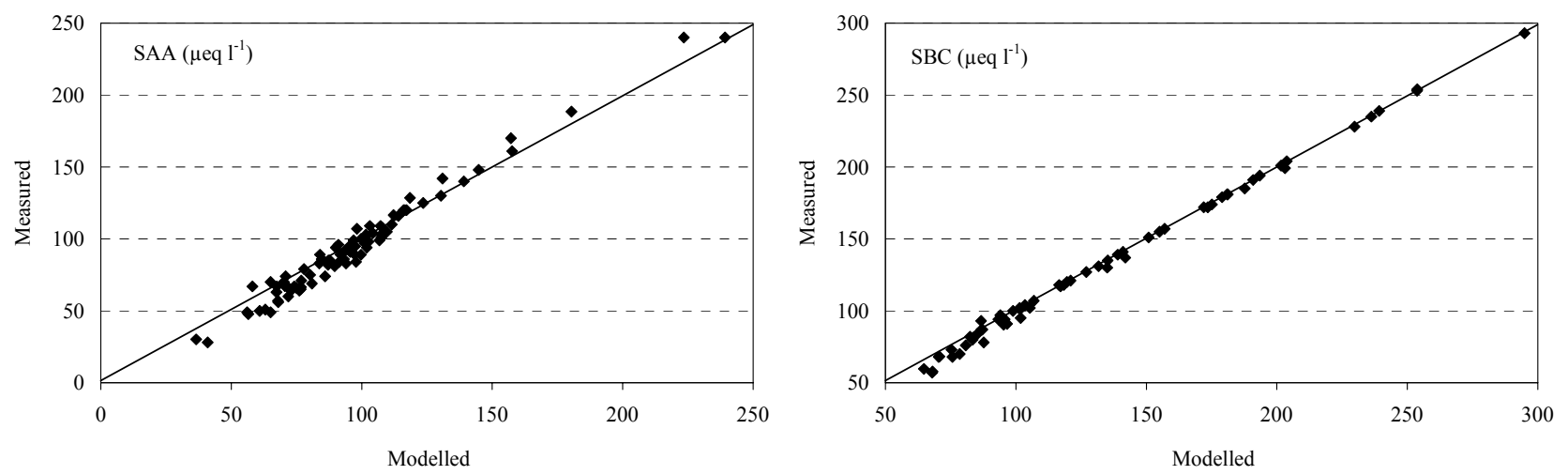

Fig. 1. Comparison of measured and modelled values of the sum of acid anions (SAA) and the sum of base cations (SBC) in the alpine lakes $(\mathrm{n}=84)$ in the target year (1985).
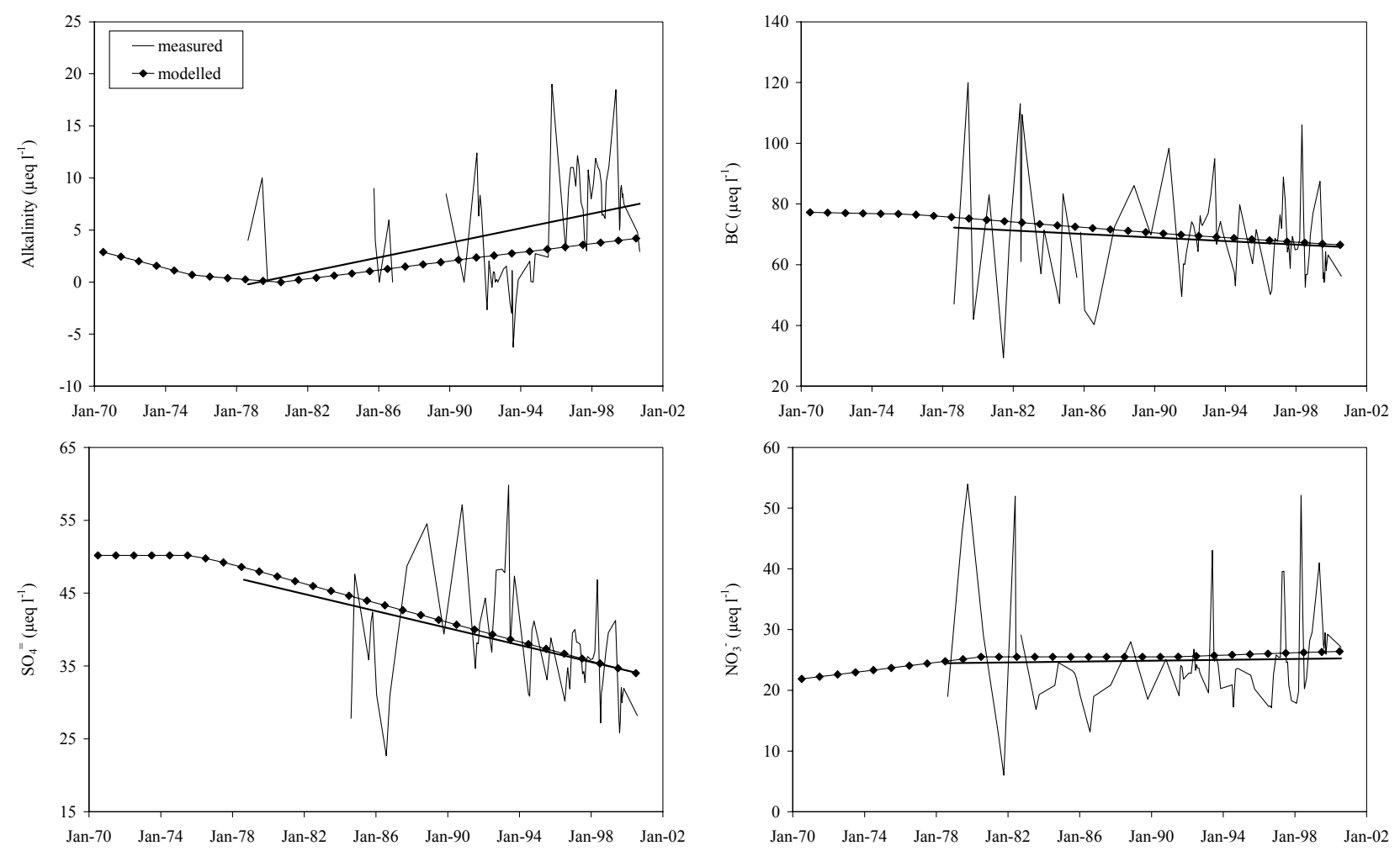

Fig. 2. Comparison between the hindcast simulation by MAGIC (modelled) and the measured data of selected variables in Lake Paione Superiore (monthly mean values and regression line). BC: base cations.

acidification period (since 1860) and in correspondence of the maximum acidifying inputs from the atmosphere (1985). Then the CLE scenario was applied to predict the response of the lakes to the changes in the deposition of $\mathrm{S}$ and $\mathrm{N}$ compounds in the next future. As explained above, the reliability of model outputs is greatly reduced by the lack of continuous series of chemical data to be used in the calibration, as well by the limited information available on the characteristics of soil and catchment. For this reason the forecast was applied to detect the chemical response of the lakes up to 2015 and not beyond. The changes in the values of the major chemical variables between the target year (1985) and
2015 are shown in table 2. The average decrease of $\mathrm{SO}_{4}{ }^{2-}$ concentration was of $45 \mu \mathrm{eq} \mathrm{l}^{-1}\left(-1.50 \mu \mathrm{eq} \mathrm{l}^{-1} \mathrm{y}^{-1}\right)$, while the nitrate content decrease of $6 \mu \mathrm{eq} 1^{-1}$ only (Tab. 2). As a consequence $\mathrm{pH}$ and $\mathrm{ANC}$ values recovered in the lakes (on average of 0.25 unit and $15 \mu \mathrm{eq} \mathrm{l}^{-1}$, respectively). BC concentrations in surface water usually increase when acidification occurs as a consequence of their release from the soil exchange complex (Reuss \& Johnson 1986). When recovery began, also BC concentrations started to decrease in the lakes and they are supposed to decrease in the next years too, at a rate of about $1.2 \mu \mathrm{eq} 1^{-1} \mathrm{y}^{-1}$ (Tab. 2). 
Tab. 2. Change in the values of the main chemical variables in lake water and in the soil between 1985 (target year) and 2015 according to the MAGIC model $(\mathrm{n}=84)$. ANC: Acid Neutralising Capacity. SBC: sum of base cations. SAA: Sum of Acid Anions. BS: Base Saturation. Ionic concentrations: $\mu$ eq $1^{-1}$. Soil BS: $\%$.

\begin{tabular}{lccccccccccc}
\hline & $\mathrm{pH}$ & $\mathrm{Ca}^{2+}$ & $\mathrm{Mg}^{2+}$ & $\mathrm{Na}^{+}$ & $\mathrm{K}^{+}$ & $\mathrm{SO}_{4}{ }^{2-}$ & $\mathrm{NO}_{3}^{-}$ & $\mathrm{ANC}$ & $\mathrm{SBC}$ & $\mathrm{SAA}$ & Soil BS \\
\hline Mean & 0.26 & -30.4 & -3.6 & -1.2 & -0.6 & -45.0 & -5.9 & 14.9 & -35.8 & -50.9 & -0.8 \\
St. Dev. & 0.32 & 9.5 & 1.5 & 0.6 & 0.3 & 9.8 & 3.0 & 9.2 & 11.2 & 10.5 & 1.2 \\
Max & 1.00 & -11.0 & -1.2 & -0.1 & 0.0 & -23.4 & 0.0 & 42.2 & -12.4 & -25.9 & 1.6 \\
Min & 0.01 & -54.4 & -7.8 & -2.8 & -1.1 & -68.5 & -16.8 & 1.0 & -64.7 & -79.6 & -3.5 \\
\hline
\end{tabular}
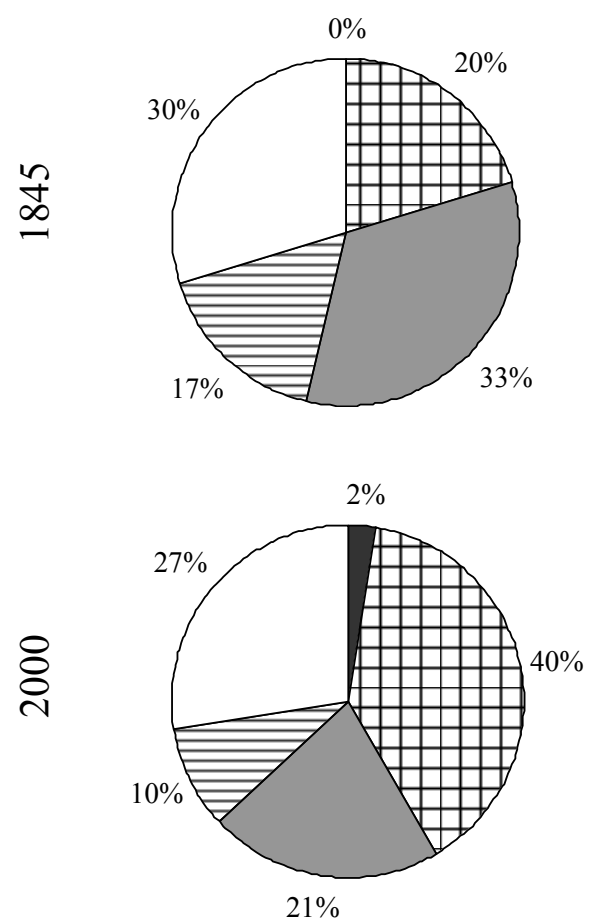

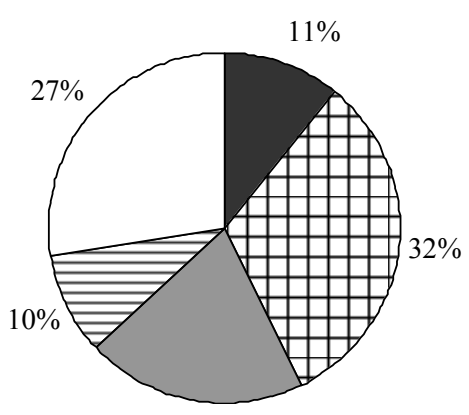

$\stackrel{\infty}{\infty}$

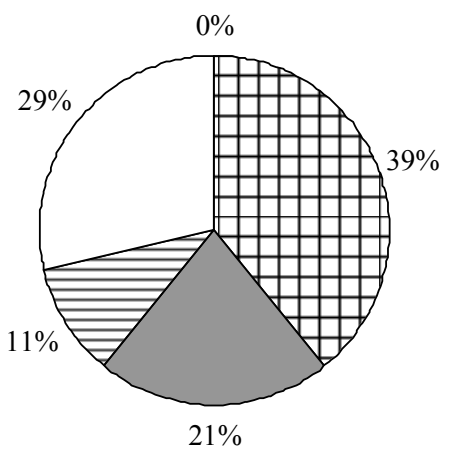

Fig. 3. ANC (Acid Neutralising Capacity) levels in the alpine lakes $(\mathrm{n}=84)$ in 1845, 1985, 2000 and 2015 as simulated by the MAGIC model.

ANC was used here to describe the pattern of acidification and recovery at the study lakes (Fig. 3). The MAGIC model simulated a recovery process in the period 1985-2000, due to the decreasing atmospheric input of $\mathrm{SO}_{4}{ }^{2-}$. Lakes with negative ANC passed from $11 \%$ of the total population to $2 \%$. A further recovery is foreseen for 2015, when, according to the model, all the lakes should have positive ANC values. If we consider $50 \mu \mathrm{eq} \mathrm{I}^{-1}$ as a critical limit for ANC, it can be seen that in 2015 almost $40 \%$ of the lakes still show ANC values under this limit. The corresponding value in 1860 was 20\% (Fig. 3).

It is evident how the improvements predicted by the model in the CLE scenario are not enough to allow a complete recovery of a pre-acidification condition in all the lakes. The main explanation of this delay can be found in the capacity of soils in the catchments to supply base cations through weathering processes. In 1845 the soil base saturation (BS) was between $15 \%$ and $25 \%$ in $80 \%$ of the lakes; despite the decreasing acidic inputs from the atmosphere, in 2015 about $65 \%$ of the lakes will be characterised by BS values below $10 \%$. The average change of BS between 1985 and 2015 is negative (Tab. 2), so indicating that recovery of soils from acidification will start later and will be slower compared to lake water. This is confirmed by the analysis of acidification and recovery considering acid sensitive lakes only, as those with ANC below $200 \mu \mathrm{eq} 1^{-1}$ (Fig. 4). According to the model, ANC concentrations in these lakes will not recover to the values found in pristine conditions by 2015 (Fig. 4a). The median value of ANC in the lakes will reach about $45 \mu \mathrm{eq} \mathrm{l}^{-1}$, compared to a median concentration of $60 \mu \mathrm{eq} 1^{-1}$ in the second half of the 19 th century. The most sensitive lakes, representing about $10 \%$ of the total population, experienced the most pronounced ANC decrease, from 40-42 $\mu \mathrm{eq} \mathrm{l}^{-1}$ at the beginning of the record to negative values (about $-2 \mu \mathrm{eq}$ $1^{-1}$ ) in the middle 1980s; then ANC recovered to positive values, but only slightly above $20 \mu \mathrm{eq} \mathrm{l}^{-1}$ (Fig. 4a). $\mathrm{BS}$ in the soils has been decreasing since the begin- 

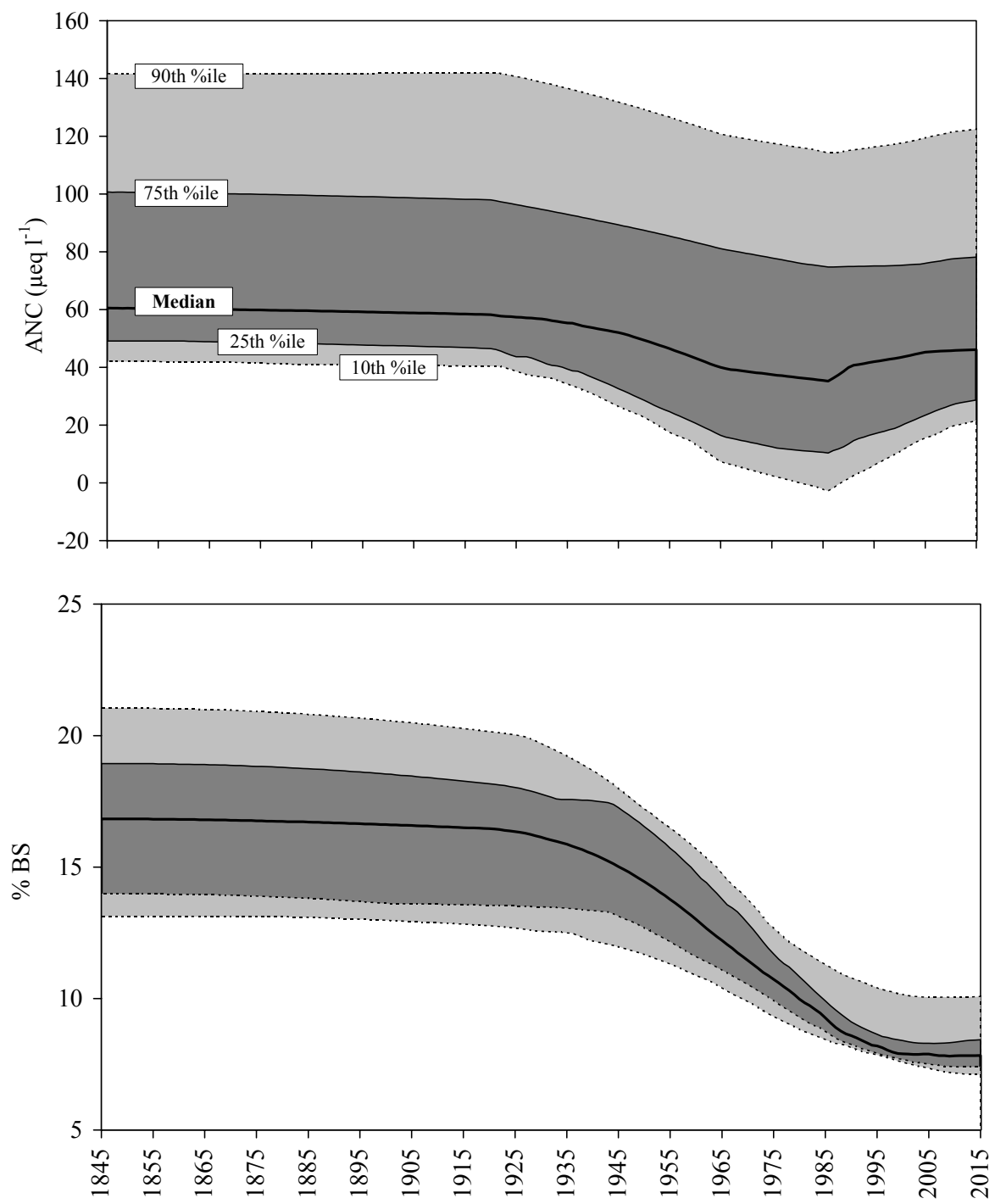

Fig. 4. ANC (Acid Neutralising Capacity, upper panel) and BS (Base Saturation, lower panel) changes at the acid sensitive lakes $\left(\right.$ ANC $<200 \mu$ eq $\left.^{-1}\right)(n=61)$ as simulated by the MAGIC model in the hindcast $(1845-1985)$ and forecast $(1985-2015)$ periods.

ning of the $20^{\text {th }}$ century, with a steep slope between 1950 and 1990. In the next decade, BS values will levelled off but a recovery is not foreseen before 2015 (Fig. 4b).

\subsubsection{Lake Paione Superiore (LPS)}

MAGIC was applied to LPS to detect the response of lake chemistry to different deposition scenarios. In particular, the model was calibrated at this site using $\mathrm{N}$ dynamics and in such a way to simulate an initial stage of $\mathrm{N}$ saturation.

To better evaluate and quantify the different role of $\mathrm{SO}_{4}{ }^{2-}, \mathrm{NO}_{3}{ }^{-}$and $\mathrm{NH}_{4}{ }^{+}$deposition in the chemical recovery of LPS, the model was run assuming the following scenarios (Fig. 5):

A: $\mathrm{SO}_{4}{ }^{2-}$ decreasing, $\mathrm{NO}_{3}{ }^{-}$and $\mathrm{NH}_{4}{ }^{+}$constant;

B: $\mathrm{SO}_{4}{ }^{2-}$ and $\mathrm{NO}_{3}{ }^{-}$decreasing, $\mathrm{NH}_{4}^{+}$constant;

$\mathrm{C}$ : $\mathrm{SO}_{4}{ }^{2-}, \mathrm{NO}_{3}{ }^{-}$and $\mathrm{NH}_{4}{ }^{+}$decreasing.
Decrease rates of $\mathrm{SO}_{4}{ }^{2-}$ and $\mathrm{NO}_{3}{ }^{-}$are those provided by the RAINS model, so that the B scenario is basically the CLE scenario of the previous application to the survey lakes. In the $\mathrm{C}$ scenario, $\mathrm{NH}_{4}{ }^{+}$was predicted to decrease at the same extent of $\mathrm{NO}_{3}^{-}$(in 2015 deposition are assumed to be about $40 \%$ of the present value). The outputs of the model clearly show how the present and future reduction of $\mathrm{SO}_{4}{ }^{2-}$ deposition alone (A scenario) does not allow a considerable chemical recovery at the study sites. A coupled reduction of $\mathrm{NH}_{4}^{+}$and $\mathrm{NO}_{3}^{-}$ deposition, as those provided in the $\mathrm{C}$ scenario, is necessary to avoid an increase of $\mathrm{NO}_{3}{ }^{-}$concentrations in lake water and to reach a satisfactory recovery of $\mathrm{pH}$ and ANC (Fig. 5).

A concentration of $20 \mu \mathrm{eq}^{-1}$ for ANC is commonly assumed as a critical limit for biota in alpine lakes (e.g. Mills \& Schindler 1986). Standing the reduction of $\mathrm{SO}_{4}{ }^{2-}$ and $\mathrm{NO}_{3}{ }^{-}$agreed under the Gothenburg Protocol, $\mathrm{NH}_{4}{ }^{+}$deposition should be reduced by $40 \%$ with respect 

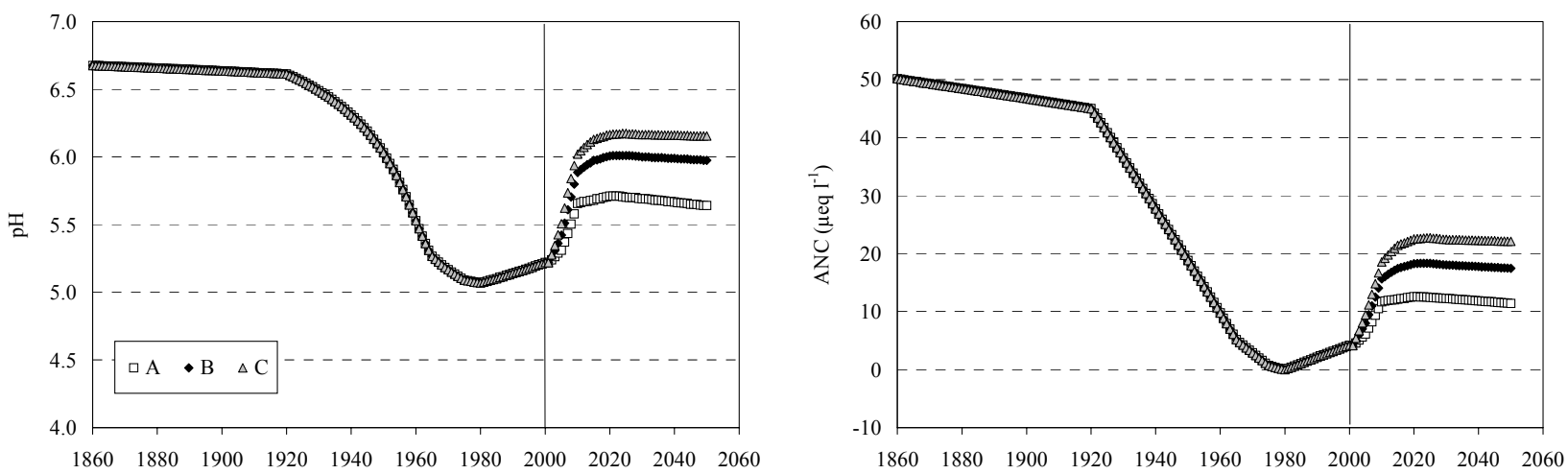

Fig. 5. Simulation of $\mathrm{pH}$ (left panel) and ANC (right panel) values in Lake Paione Superiore under three different scenarios of atmospheric deposition. A: $\mathrm{SO}_{4}{ }^{2-}$ decreasing, $\mathrm{NO}_{3}^{-}$and $\mathrm{NH}_{4}^{+}$constant; $\mathrm{B}: \mathrm{SO}_{4}{ }^{2-}$ and $\mathrm{NO}_{3}^{-}$decreasing and $\mathrm{NH}_{4}{ }^{+}$constant; $\mathrm{C}^{-} \mathrm{SO}_{4}{ }^{2-}$, $\mathrm{NO}_{3}{ }^{-}$and $\mathrm{NH}_{4}^{+}$decreasing.

to present value to reach the ANC target by 2015. It should be highlighted that deposition of $\mathrm{NH}_{4}{ }^{+}$is remarkably high in the study area and the oxidation of $\mathrm{NH}_{4}^{+}$to $\mathrm{NO}_{3}^{-}$represents is an important source of potential acidity to surface waters (Schuurkes \& Mosello 1986).

Model outputs for LPS were tested considering previous results from paleolimnological studies at this site (Guilizzoni et al. 1996). According to the model hindcast, $\mathrm{pH}$ of LPS in pristine condition, before the onset of acidification, was above 6.5 (Rogora et al. 2003b). It started to decrease in 1920-30 and the lowest values were reached in the $1980 \mathrm{~s}$, in correspondence with the highest levels of $\mathrm{SO}_{4}{ }^{2-}$ in lake water (Fig. 2). These results fit well with the carbonaceous particle profiles for LPS reconstructed from sediment analysis (Guilizzoni et al. 1996), which showed the start of the particle record at the beginning of the $20^{\text {th }}$ century and a rapid increase of concentration from about 1950-60. Paleolimnological investigations showed also a marked increase in the concentration of $\mathrm{N}$ in the most recent sediments and a decrease of the $\mathrm{C}: \mathrm{N}$ ratio, which could be related to atmospheric $\mathrm{N}$ load (Guilizzoni et al. 1996). These findings agree with the positive trend of $\mathrm{NO}_{3}{ }^{-}$concentrations in lake water simulated by MAGIC since 1920s. As a consequence of the progressive accumulation of $\mathrm{N}$ in the soil of the catchment, the model also predicted a decrease of the $\mathrm{C}: \mathrm{N}$ ratio in the soil organic pool (Rogora et al. 2003b).

\subsection{Confounding factors in the chemical trends at mountain lakes}

Of the selected survey lakes, about $25 \%$ are characterized by high buffer capacity (ANC values above 200 $\mu$ eq $\mathrm{I}^{-1}$ ) (Tab. 1). For these lakes the effects of future scenarios will be negligible in all cases as regard acidification. The analysis of long-term data series available for a limited number of sites proved evidence of the influence of other factors than atmospheric deposition on lake chemistry (Rogora et al. 2001, 2003a). In spite of the widespread decrease in atmospheric $\mathrm{SO}_{4}{ }^{2-}$ inputs, some lakes showed an increasing concentration of $\mathrm{SO}_{4}{ }^{2-}$, silica and $\mathrm{BC}$ over a period of about 15 years. Enhanced weathering rates, resulting from recent climate warming, were hypothesised as the main explanation for these trends (Rogora et al. 2003a). To test this hypothesis, data series of air temperature, precipitation, snow depth and duration at some sites in the study area have been investigated. The results clearly showed increasing trends of temperature at most sites, particularly evident in the last 30 years, and a reduction of snow depth at high-altitude sites since the 1930s; in particular a distinct decrease of snow depth and duration has been recorded in the last 15 years (Rogora et al. 2003a). Temperature increase coupled with the partial or total disappearance of permanent snow fields could enhance weathering processes and increase the solute export to lake water. This effect in the next future will act in conjunction with other driving forces such as atmospheric input to determine the chemical variations in alpine lakes (Wright \& Schindler 1995; Skjelkvale \& Wright 1998).

Also the episodic deposition of Saharan dust, both in dry form or dissolved in rain, has been identified as an important source of alkalinity, BC and nutrients to alpine lakes. Unfortunately the contribution of dust to the chemical variability of alpine lakes can be hardly estimated, owing to the lack of quantitative studies in remote areas (Psenner 1999). Nonetheless, long-term series of precipitation data showed how the so-called red rains carry a relevant fraction of the total calcium deposition affecting the study area and can buffer the mineral acidity of atmospheric deposition (Rogora et al. 2001). Furthermore, an increased occurrence and intensity of alkaline events has been detected in recent years. This could be related to an increase export of Saharan dust from arid regions together with changes in the circulation pattern over the Mediterranean area (Rogora et al., in press).

At present in MAGIC there is no procedure to directly simulate the effects of climate change on surface water. Nevertheless, for each compartment, sources or 
sinks of the major ions can be specified in the model. $\mathrm{BC}$ input from Saharan episodes can be simulated through a progressive increase of $\mathrm{BC}$ deposition, as suggested in Camarero et al. (2004, this volume). Similarly, an increase of solute concentrations in surface water could be simulated by adding sources of the weathering products through time with a constant or varying slope. This possibility has not been tested yet but it may represents a starting point for a further reevaluation and improvement of the model.

\section{CONCLUSIONS}

Some remote lakes in the Alps for which long-term data exist have shown signs of chemical recovery in recent years (Mosello et al. 2002) and will respond to further decrease in atmospheric deposition in the next decades. In this scenario, climate change will become increasingly important. A critical point will be the effect of warming on $\mathrm{N}$ dynamics in terrestrial and aquatic ecosystems. In mountain areas, the chemical variability of lake water will probably be determined, beside the geology of bedrock, by temperature variations and precipitation regime, especially in terms of rain to snow ratio, rather than by acid deposition. On the other hand, the magnitude and direction of climate change will be dependent on local meteorology and site-specific processes, making it difficult to foresee the effects on ecosystems.

The results emerging from this study should be interpreted with respect to existing uncertainties in input data. Measured data, particularly long-term data series, such as those available for LPS, are invaluable for a robust calibration of dynamic models like MAGIC. In spite of the uncertainties in model predictions, this study, like others performed at a European and international level (e.g. Wright et al. 1994, 1998; Jenkins \& Cullen 2001; Jenkins et al. 2003), highlighted the advantage of using dynamic models in the assessment of emission reduction strategies rather than steady state models or critical load calculations.

The degree to which recovery can be achieved by reducing either $\mathrm{S}$ or $\mathrm{N}$ beyond the agreed requirements of the Gothenburg Protocol, is site specific and will depend on the current deposition fluxes of $\mathrm{S}$ and $\mathrm{N}$, the accumulated historical $\mathrm{S}$ and $\mathrm{N}$ fluxes and the current status of N saturation (Jenkins \& Cullen 2001; Jenkins et al. 2003). The model outputs for alpine lakes in North-Western Italy clearly demonstrated the benefits of achieving the emission reductions in both $\mathrm{S}$ and $\mathrm{N}$ agreed under the Gothenburg Protocol. It is clear that current levels of $\mathrm{S}$ and $\mathrm{N}$ emissions, while showing a substantial decline from their peak levels in the 1980s, must be reduced even more to protect freshwaters from further acidification. Highly desirable would be a reduction of $\mathrm{N}$ deposition both in the oxidised and reduced form. Anyway, the critical load of $\mathrm{N}$ to terrestrial and aquatic ecosystems may depend in the future on the climate regime to which they are subject. Concurrent long-term changes in environmental driving variables should be taken into account in the ongoing negotiations to reduce $\mathrm{N}$ emissions in the future decades.

\section{ACKNOWLEDGMENTS}

This research was partially funded by the EU Projects EMERGE (EU contract EVK1-CT-1999-00032) and RECOVER:2010 (EU contract EVK1-CT-199900018). I would like to thank A. Barbieri of the Cantonal Agency for Water Protection of Bellinzona $(\mathrm{CH})$, for providing chemical data of the lakes in Canton Ticino. I am indebted to R. Helliwell and R.F. Wright for their help in the modelling, and to A. Marchetto, S. Arisci and R. Mosello for critical reading of the paper.

\section{REFERENCES}

Aber, J.D., K.J. Nadelhoffer, P. Steudler \& J.M Mellilo. 1989. Nitrogen saturation in northern forest ecosystems. Bioscience, 39: 378-386.

Alcamo, J., R. Shaw \& L Hordijk (Eds). 1990. The RAINS model of acidification. Kluwer Academic Publishers, Dordrecht, The Netherlands.

Alewell, C., B. Manderscheid, H. Meesenburg, \& J. Bittersohl. 2000. Is acidification still an ecological threat? Nature, 407: 856-857.

Boggero, A., A. Barbieri, M. Conedera, A. Marchetto, R. Mosello \& G.A. Tartari. 1993. Land cover as a factor influencing the chemistry of mountain lakes in the Western Alps. Verh. int. Ver. Limnol., 25: 772-775.

Camarero, L., R.F. Wright, J. Catalan \& M. Ventura. 2004. Application of MAGIC to Lake Redó (Central Pyrenees): an assessment of the effects of possible climate driven changes in atmospheric precipitation, base cation deposition, and weathering rates on lake water chemistry. $J$. Limnol., 63(1): 123-132.

Carollo, A., F. Contardi, V. Libera \& A. Rolla. 1985. Hydroclimatic cartography of the Lake Maggiore drainage basin. Mem. Ist. ital. Idrobiol., 46: 21-40.

Cosby, B.J., G.M. Hornberger, J.N. Galloway \& R.F. Wright. 1985a. Modelling the effects of acid deposition: Assessment of a lumped parameter model of soil water and streamwater chemistry. Water Res. Res., 21: 51-63.

Cosby, B.J., G.M. Hornberger, J.N. Galloway \& R.F. Wright. 1985b. Time scales of acidification: A quantitative model for estimating freshwater acidification. Env. Sci. Tech., 19: 1144-1149.

Cosby, B.J., G.M. Hornberger, R.F. Wright \& J.N. Galloway. 1986. Modelling the effects of acid deposition: Control of long term sulphate dynamics by soil sulphate adsorption. Water Res. Res., 22: 1283-1291.

Cosby, B.J., R.C. Ferrier, A. Jenkins \& R.F. Wright. 2001. Modelling the effects of acid deposition - fifteen years of MAGIC: refinements, adjustments and inclusion of nitrogen dynamics. Hydrol. Earth System Sci., 5: 499-517.

Ferrier, R.C., A. Jenkins, R.F. Wright, W. Schöpp \& H. Barth. 2001. Assessment of recovery of European surface waters from acidification, 1970-2000: Introduction to the Special Issue. Hydrol. Earth System Sci., 5: 274-282.

Guilizzoni, P., A. Marchetto, A. Lami, N.G. Cameron, P.G. Appleby, N.L. Rose, Ø.A. Schnell, C.A. Belis, A. Giorgis \& L. Guzzi. 1996. The environmental history of a mountain lake (Lago Paione Superiore, Central Alps, Italy) for the last c. 100 years: a multidisciplinary, paleolimnological study. J. Paleolimnol., 15: 245-264. 
IPCC. 2001. Climate Change 2001. The Scientific Basis. Contribution of Working Group I to the Third Assessment Report of the Intergovernmental Panel on Climate Change. J.T. Houghton, Y. Ding, D.J. Griggs, M. Noguer, P.J. van der Linden \& D. Xiaosu (Eds), Cambridge University Press, UK: $881 \mathrm{pp}$.

Jenkins, A., R.C. Ferrier \& B.J. Cosby. 1997. A dynamic model for assessing the impact of coupled sulphur and nitrogen deposition scenarios on surface water acidification. J. Hydrol., 197: 111-127.

Jenkins, A. \& J. Cullen. 2001. An assessment of the potential impact of the Gothenburg Protocol on surface water chemistry using the dynamic MAGIC model at acid sensitive sites in the UK. Hydrol. Earth System Sci., 5: 529541 .

Jenkins, A., L. Camarero, B.J. Cosby, R. Ferrier, M. Forsius, R. Helliwell, J. Kopáček, V. Majer, F. Moldan, M. Posch, M. Rogora, W. Schöpp \& R. Wright. 2003. The recovery of European surface waters from acidification. Hydrol. Earth System Sci., 7: 447-455.

Kernan, M.R.S. \& J. Catalan. 2003. A typology for European mountain lakes. Proceedings of the Symposium "How to assess and monitor ecological quality in freshwaters", 2325 October 2003, Helsinki, Finland. Tema Nord 2003:547. Nordic Council of Ministers, Copenhagen: 214 pp.

Kaste, Ø., A. Henriksen \& A. Hindar. 1997. Retention of atmospherically-derived nitrogen in subcatchments Bjerkreim River In Southwestern Norway. Ambio, 26: 296-303.

Kopáček, J., E. Stuchlík, J. Veselý, J. Schaumburg, I.C. Anderson, J. Fott, J. Hejzlar \& J. Vrba. 2002. Hysteresis in reversal of Central European mountain lakes from atmospheric acidification. Water Air Soil Pollut: Focus, 2: 91-114.

Loÿe-Pilot, M.D., J.M. Martin \& J. Morelli. 1986. Influence of Saharan dust on the rain acidity and atmospheric input to the Mediterranean. Nature, 321: 427-428.

Marchetto, A., A. Barbieri, R. Mosello \& G.A. Tartari. 1994 Acidification and weathering processes in high mountain lakes in Southern Alps. Hydrobiologia, 274: 75-81.

Marchetto, A., R. Mosello, R. Psenner, G. Bendetta, A. Boggero, D. Tait \& G.A. Tartari. 1995. Factors affecting water chemistry of alpine lakes. Aquat. Sci., 55: 81-89.

Marchetto, A., R. Mosello, M. Rogora, M. Manca, A. Boggero, G. Morabito, S. Musazzi, G.A. Tartari, A.M. Nocentini, A. Pugnetti, R. Bettinetti, P. Panzani, M. Armiraglio, P. Cammarano \& A. Lami. 2004. The chemical and biological response of two remote mountain lakes in the Southern Central Alps (Italy) to twenty years of changing physical and chemical climate. J. Limnol., 63(1): 77-89

Mills, K.H. \& D.W. Schindler. 1986. Biological indicators of lake acidification. Wat. Air Soil Pollut., 30: 779-789.

Mitchell, M.J., C.T. Driscoll, J.S. Kahl, G.E. Likens, P.S. Murdoch \& L.H. Pardo. 1996. Climatic control of nitrate loss from forested watersheds in the northeast United States. Environ. Sci. Technol., 30: 2609-2612.

Mosello, R. \& A. Marchetto. 1996. Chemistry of atmospheric wet deposition in Italy. Results from a five year study. Ambio, 25: 21-25.

Mosello, R., B.M. Wathne, L. Lien \& J. Birks. 1995. AL:PE Projects: water chemistry and critical loads. Water Air Soil Pollut., 85: 493-498.

Mosello, R., A. Marchetto, M.C. Brizzio, G.A. Tartari \& M Rogora. 1999. Pluriannual evolution of the hydrochemistry of two alpine lakes (Lake Paione Inferiore and Lake Paione Superiore, Ossola Valley) in relation to atmospheric loads. J. Limnol., 58 (1): 43-49.

Mosello, R., A. Calderoni, A. Marchetto, M.C. Brizzio, M Rogora, S. Passera \& G.A. Tartari. 2001. Nitrogen budget of Lago Maggiore: the relative importance of atmospheric deposition and catchment sources. J. Limnol., 60: 27-40.

Mosello, R., A. Barbieri, G. Bendetta, A. Boggero, A. Marchetto, R. Psenner, D. Tait \& G.A. Tartari. 1992. Quantification of the susceptibility of alpine lakes to acidification. Mem. Ist. ital. Idrobiol., 52: 355-386.

Mosello, A. Lami, A. Marchetto, M. Rogora, B. Wathne, L. Lien, J. Catalan, L. Camarero, M. Ventura, R. Psenner, K. Koinig, H. Thies, S. Sommaruga-Wögrath, U. Nickus, D. Tait, B. Thaler, A. Barbieri \& R. Harriman. 2002. Trends in the water chemistry of high altitude lakes in Europe. Water Air Soil Pollut: Focus, 2: 75-89.

Psenner, R. 1999. Living in a dusty world: airborne dust as a key factor for alpine lakes. Water Air Soil Poll., 112: 217-227.

Reuss, J.O. \& D.W. Johnson. 1986. Acid deposition and the acidification of soil and water. Ecological Studies No. 59. Springer-Verlag, New York: 118 pp.

Rogora, M., A. Marchetto \& R. Mosello. 2001. Trends in the chemistry of atmospheric deposition and surface waters in the Lago Maggiore watershed. Hydrol. Earth System Sci., 5: 379-390.

Rogora, M., R. Mosello \& S. Arisci. 2003a. The effect of climate warming on the hydrochemistry of alpine lakes. Water Air Soil Poll., 148: 347-361.

Rogora, M., A. Marchetto \& R. Mosello. 2003b. Modelling the effects of the deposition of acidity and nitrogen on selected lakes and streams in central alps (Italy). Hydrol. Earth System Sci., 7: 540-551.

Rogora, M., R. Mosello \& A. Marchetto. (2004). Long-term trends in the chemistry of atmospheric deposition in NW Italy: the role of increasing Saharan dust deposition. Tellus $B$ : (in press)

Schuurkes, J.A.A.R. and Mosello, R. 1988. The role of external ammonium inputs in freshwater acidification. Schweiz. Z. Hydrol. 50: 71-85.

Skjelkvale, B.L. \& R.F. Wright. 1998. Mountain lakes; sensitivity to acid deposition and global climate change. Ambio, 27: 280-286.

Skjelkvåle, B.L:, C.D. Evans, T. Larssen, A. Hindar \& G.G. Raddum. 2003. Recovery from acidification in European surface waters: a view to the future. Ambio, 30: 170-175.

Sommaruga-Wögrath, S., K.A. Koinig, R. Schmidt, R. Sommaruga, R. Tessadri \& R. Psenner. 1997. Temperature effects on the acidity of remote alpine lakes. Nature, 387 : 64-67.

UN-ECE. 1999. Protocol to the 1979 Convention on Longrange Transboundary Air Pollution to abate acidification, eutrophication and ground-level ozone. United Nations, Economic Commission for Europe, Geneva, Switzerland: 63 pp.

Wright, R.F. 1998. Effect of increased $\mathrm{CO}_{2}$ and temperature on run-off chemistry at a forested catchment in Southern Norway (CLIMEX Project). Ecosystems, 1: 216-225.

Wright, R.F. \& D.W. Schindler. 1995. Interactions of acid rain and global changes: effects on terrestrial and aquatic ecosystems. Water Air Soil Poll., 85: 85-99.

Wright, R.F. \& A. Jenkins. 2001. Climate change as a confounding factor in reversibility of acidification: RAIN and CLIMEX projects. Hydrol. Earth System Sci., 5: 477-486.

Wright, R.F., B.J. Cosby, R.C. Ferrier, A. Jenkins, A. Bulger \& R. Harriman. 1994. Changes in acidification of lochs in Galloway, southwestern Scotland, 1979-1988: The MAGIC model used to evaluate the role of afforestation, calculate critical loads and predict fish status. J. Hydrol., 161: $257-285$

Wright, R.F., C. Alewell, J.M. Cullen, C.D. Evans, A Marchetto, F. Moldan, A. Prechtel \& M. Rogora. 2001. Trends in nitrogen deposition and leaching in acid sensitive streams in Europe. Hydrol. Earth System Sci., 5: 299 310 . 